Setyo Purwoto, Rusdiyantoro, \& Budi Prijo S. : Treatment Koagulan, Filtrasi, Ferrolite, Manganese Greensand, dan Resin Pada Air Baku Dalam Penurunan TDS, Kekeruhan, Kesadahan, Khlorida, Mangan, dan E Koli

\title{
TREATMENT KOAGULAN, FILTRASI, FERROLITE, MANGANESE GREENSAND, DAN RESIN PADA AIR BAKU DALAM PENURUNAN TDS, KEKERUHAN, KESADAHAN, KHLORIDA, MANGAN, DAN E KOLI
}

\author{
Setyo Purwoto ${ }^{1)}$, Rusdiyantoro ${ }^{2)}$, Budi Prijo Sembodo ${ }^{3)}$ \\ ${ }^{1)}$ Program Studi Teknik Lingkungan, ${ }^{2)}$ Program Studi Teknik Industri, ${ }^{3)}$ Program Studi Teknik \\ Elektro \\ Fakultas Teknik Universitas PGRI Adi Buana Surabaya \\ Email : setyopurwoto.enviro@gmail.com
}

\begin{abstract}
Abstrak
Parameter air bersih di Indonesia diatur menurut peraturan menteri kesehatan Republik Indonesia nomor : 416/Menkes/Per/IX/1990. Penelitian ini mengkaji kemampuan penurunan parameter parameter Total Disolved Solid (TDS), kekeruhan, kesadahan total (total hardness), khlorida, Mangan, dan Total Coliform (E koli) dengan menggunakan perlakuan koagulan, filtrasi, ferrolite, manganese greensand, dan resin pada air. Metode yang digunakan adalah : proses pengolahan bahan baku air diawali dengan pembubuhan Sucolite SP 211 sebagai Coagulant Aid pada tanki koagulan, kemudian treatment filtrasi menggunakan sedimen poly propilena (SPP) pada housing filter. Selanjutnya berturut turut treatment Ferrolite dan Manganese Greensand pada housing filter, resin anion pada tabung FRP, dan resin kation pada tabung FRP. Treatment koagulan, filtrasi, ferrolite, manganese greensand, dan resin pada air baku dapat menurunkan Total Disolved Solid (TDS) $1.360 \mathrm{mg} / \mathrm{L}$, kekeruhan sebesar 6,3 skala Turbidity NTU, kesadahan total (total hardness) 265,634 mg / L CaCO3, khlorida 292,878 mg / L Cl -, Mangan 1,235 mg/L Mn, dan Total Coliform (E koli) 3.140 MPN/100mL
\end{abstract}

Katakunci : Koagulan, Ferrolite, Manganese Greensand, Resin Kation Anion.

\begin{abstract}
Parameters of clean water in Indonesia are regulated according to the Minister of Health of the Republic of Indonesia number: 416/MENKES/PER/IX/1990. This study examines the ability to reduce parameters Total Disolved Solid, turbidity, total hardness, chloride, manganese, and Total Coliform using treatment coagulant, filtration, ferrolite, manganese greensand, and resin. The method used was as follows: the raw material processing of water began with the added Sucolite SP 211 as coagulant aid on the coagulant tank, then the treatment of filtration using poly propylene sediment (SPP) in housing filter. Next was the successive treatments; ferrolite and manganese greensand on the housing filters, anion resins on the FRP tubes, and cation resins on the FRP tubes. In conclusion, the coagulant treatment, filtration, ferrolite, manganese greensand, and resin on the raw water can decrease the following: Total Disolved Solid (TDS) of $1.360 \mathrm{mg} / \mathrm{L}$, turbidity of $6.3 \mathrm{NTU}$ turbidity scale, total hardness of $265.634 \mathrm{mg} / \mathrm{L} \mathrm{CaCO3}$, chloride of $292.878 \mathrm{mg} / \mathrm{L} \mathrm{Cl}$, manganese of $1.235 \mathrm{mg} / \mathrm{L} \mathrm{Mn}$ and total coliform bacteria(e coli) of $3.140 \mathrm{MPN} / 100 \mathrm{~mL}$.
\end{abstract}

Keywords: Coagulant, Ferrolite, Manganese Greensand, Anion Cation Resin. 
Setyo Purwoto, Rusdiyantoro, \& Budi Prijo S. : Treatment Koagulan, Filtrasi, Ferrolite, Manganese Greensand, dan Resin Pada Air Baku Dalam Penurunan TDS, Kekeruhan, Kesadahan, Khlorida, Mangan, dan E Koli

\section{PENDAHULUAN}

Fenomena ketidak terpenuhinya kriteria air bersih pada air tanah saat ini telah menjadi masalah untuk memenuhi kebutuhan air bersih sehari hari. Salah satu temuan dalam hal penurunan parameter air bersih yang dilakukan dengan menggunakan treatment Coagulant Aid, Pasir Silika, Ferrolite, Manganese Greensand, Resin Sintetis (kation anion), dan membrane RO diperoleh hasil penurunan parameter air bersih berturut turut : Kekeruhan 150.85 Skala NTU, Warna 148 Unit PtCo, Besi $8,71 \mathrm{mg} / \mathrm{L}$ Fe, Kesadahan Total 71.43 $\mathrm{mg} / \mathrm{L} \mathrm{CaCO}$, Seng $0,07 \mathrm{mg} / \mathrm{L} \mathrm{Zn}$, Sulfat $24.08 \mathrm{mg} / \mathrm{L}$ SO4, Detergent 0.29 $\mathrm{mg} / \mathrm{L}$ LAS. Khusus untuk penurunan Total koliform sebesar 600 MPN (Purwoto et al., 2017). Menurut Permenkes Republik Indonesia nomor : 416/Menkes/Per/IX/1990 tentang persyaratan kualitas air bersih, dimana kandungan Total Disolved Solid (TDS) maksimal $1500 \mathrm{Mg} / \mathrm{L}$, Kekeruhan 25 skala NTU, Besi 1,0 mg/L, Mangan 0,5 $\mathrm{mg} / \mathrm{L}$, Klorida $600 \mathrm{mg} / \mathrm{L}$, kesadahan total (sebagai CaC03) $500 \mathrm{mg} / \mathrm{L}$, Khlorida $600 \mathrm{mg} / \mathrm{L} \quad \mathrm{Cl}$, dan Total Bakteri Coliform 10 (Jumlah per $100 \mathrm{ml}$ sampel) pada air perpipaan. Penurunan kadar mineral kation anion sebagai parameter air bersih dalam air dapat dilakukan diantaranya dengan : koagulan, filtrasi dan absorbsi menggunakan sediment poly propylene (SPP), pengikatan kadar $\mathrm{Fe}$ dan $\mathrm{Mn}$ menggunakan ferrolite dan atau Manganese Green Sand, dilanjutkan dengan treatment Ion Exchanger menggunakan resin anion dan resin kation guna penukaran anion kation dalam air.

Tujuan penelitian ini untuk mengetahui kemampuan penurunan parameter parameter Total Disolved Solid (TDS), kekeruhan, kesadahan total (total hardness), khlorida, Mangan, dan Total Coliform (e koli) dengan menggunakan perlakuan koagulan, filtrasi, ferrolite, manganese greensand, dan resin pada air. Treatment $\underline{\text { Sucolite }}$
SP 211 sebagai koagulan berupa cairan tidak berwarna dan tidak berbau ; $\mathrm{pH}$ pada suhu $20^{\circ} \mathrm{C}$ sebesar 11-11,5 ; berat jenis $1,35 \mathrm{gr} / \mathrm{cm}^{3}$.; kadar $\mathrm{Al}_{2} \mathrm{O}_{3}$ yaitu $4,66 \%$; pH larutan 2\% 3,553, bagian yang tidak larut dalam air 0,060\% (Purwoto, S., 2016).

Penggunaan Sedimen Poly Propilena (SPP) sebagai penyaring air dari kandungan lumpur, pasir, tanah dan partikel kotoran zat padat terlarut air lainnya sehingga menghasilkan air jernih, bersih bebas dari pencemaran zat padat terlarut dalam air. Fungsi Ferrolite untuk menghilangkan kandungan besi tingkat tinggi $(\mathrm{Fe})$, bau besi yang menyengat, Mangan (Mn2+), warna kuning di air tanah atau air PDAM.

Perlakuan Manganese Greensand Absorben zat besi dan mangan, dimana Reaksi dari $\mathrm{Fe}^{2+}$ dan $\mathrm{Mn}^{2+}$ dalam air dengan oksida mangan tinggi (higher mangan oxide) menghasilkan filtrat yang mengandung ferri-oksida dan mangan-dioksida yang tak larut dalam air dan dapat dipisahkan dengan pengendapan dan penyaringan. Removal $\mathrm{Mn}^{2+}$ dapat dilakukan dengan adsorbs oleh Mangan oksida dalam manganese oxide coated zeolite (MOCZ) (Taffarel, 2010).

Kinerja resin merupakan proses terjadinya pertukaran ion (IonExchanger) antara kation-anion dalam resin dengan anion-kation yang terdapat pada larutan yang diperlakukan. Dalam proses demineralisasi, maka sebagai contoh ; kation $\mathrm{Na}^{+}$dan anion $\mathrm{Cl}^{-}$disisihkan dari air dan solid resin melepas ion $\mathrm{H}^{+}$ untuk ditukar dengan ion $\mathrm{Na}^{+}$, serta $\mathrm{OH}^{-}$ditukar dengan $\mathrm{Cl}^{-}$dari air sehingga kandungan $\mathrm{Na}^{+}$dan $\mathrm{Cl}^{-}$dalam air menjadi berkurang atau hilang (Montgomery, 2005). Sedangkan Purwoto, S. (2009) menyimpulkan bahwa desalinasi air payau dapat dilakukan secara ion exchange dengan treatmen pasangan resin sintetis kation dan anion baik terpisah maupun secara campuran keduanya._Air sungai yang keruh jika dilakukan pengolahan 
Setyo Purwoto, Rusdiyantoro, \& Budi Prijo S. : Treatment Koagulan, Filtrasi, Ferrolite, Manganese Greensand, dan Resin Pada Air Baku Dalam Penurunan TDS, Kekeruhan, Kesadahan, Khlorida, Mangan, dan E Koli

(treatment) menggunakan koagulan dilanjutkan dengan filtrasi, kemudian absorben zeolit dan MGS, filter pasir silika dan diakhiri menggunakan resin sintetis kation dan resin sintetis anion dapat menghasilkan air yang jernih (Purwoto, S., 2015)

Purwoto, S. et al. (2014) menyatakan bahwa treatment : Sediment Poly Propylene, Carbon Block, Manganese Zeolite, Ion Exchange, and Reverse Osmosis (RO) untuk acuan persyaratan air bersih mampu mengurangi beban beberapa parameter, diantaranya adalah ; Total Disolved Solid (TDS) 2686 ppm, Kesadahan Total 371,43 mg / L CaCO3, Klorida 1144 ppm, Coliform Total 4 MPN / $100 \mathrm{~mL}$, Besi 0,18 ppm, Sodium 737,70 ppm, Seng 0,08 ppm, Sulfat 24,56 ppm, Zat Organik 15,03 $\mathrm{mg} / \mathrm{L} \mathrm{KMnO} 4$, dan Deterjen 0,10 mg / L LAS.

Removal parameter air bersih oleh perpaduan treatment coagulant aid, Filtrasi sediment polipropylena (SPP), dan absorsi manganese greensand, dilanjutkan dengan Ion Exchanger sebagai berikut ; Klorida 2028 ppm, Besi 0,22 ppm, Total Disolved Solid (TDS) 3366 ppm, Kesadahan total 621,43 mg / L, CaCO3 , Zat Organik 19,84 mg / L KMnO4, Seng 0,08 ppm, Sulfat 40,46 ppm, dan Deterjen 0,12 mg / L LAS (Nurhayati et al., 2014).
Treatment ferrolite, manganese zeolite, dan ion exchanger berupa resin anion dan resin kation pada air tanah menurut (Purwoto et al. 2016) mampu meremoval kandungan beban kekeruhan, warna, dan logam logam Besi, Kromium, serta Mangan hingga menjadi kriteria parameter air bersih mengacu pada permenkes nomor 416/Menkes/Per/IX/1990.

Hasil temuan dalam penelitian ini adalah kemampuan penurunan parameter parameter Total Disolved Solid (TDS), kekeruhan, kesadahan total (total hardness), khlorida, Mangan, dan Total Coliform (e koli) dengan menggunakan perlakuan koagulan, filtrasi, ferrolite, manganese greensand, dan resin pada air.

\section{METODE}

Rancangan penelitian dalam
penelitian ini dimulai dengan
pengambilan sampel air baku, kemudian
dilakukan pengolahan bahan baku air
diawali dengan pembubuhan Sucolite SP
211 sebagai Coagulant Aid pada tanki
koagulan (1), kemudian treatment
filtrasi menggunakan sedimen poly
propilena (SPP) pada housing filter (2).
Selanjutnya berturut turut treatment ;
Ferrolite dan Manganese Greensand
pada housing filter (3) dan (4), resin
anion pada tabung FRP (5), dan resin
kation pada tabung FRP (6)
sebagaimana Gambar 1.


Setyo Purwoto, Rusdiyantoro, \& Budi Prijo S. : Treatment Koagulan, Filtrasi, Ferrolite, Manganese Greensand, dan Resin Pada Air Baku Dalam Penurunan TDS, Kekeruhan, Kesadahan, Khlorida, Mangan, dan E Koli

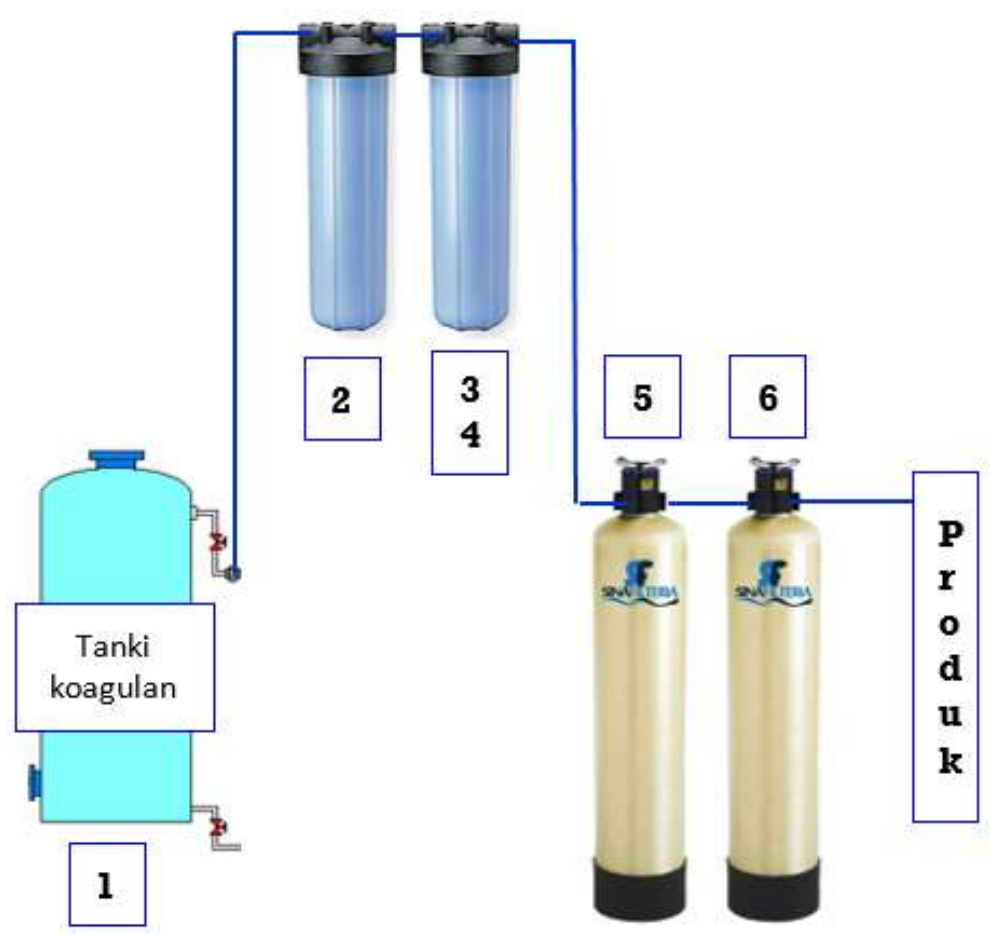

Gambar 1. Desain Model Treatment Pengolahan Air

Keterangan Gambar 1 :

$(1)=$ treatment Coagulant Aid pada tanki koagulan

(2) $=$ treatment filtrasi menggunakan sedimen poly propilena (SPP) pada housing filter

(3) dan (4) = treatment Ferrolite pada housing filter atau tabung FRP dan Manganese

Greensand pada housing filter

(5) $=$ Treatment resin anion pada tabung FRP

(6) $=$ Treatment resin kation pada tabung FRP

Coagulant Aid yang digunakan dalam penelitin ini adalah Sucolite SP 211 berupa cairan tidak berwarna dan tidak berbau, $\mathrm{pH}$ pada suhu $20^{\circ} \mathrm{C}$ sebesar $11-11,5$, berat jenis $1,35 \mathrm{gr} / \mathrm{cm}^{3}$, kadar $\mathrm{Al}_{2} \mathrm{O}_{3}$ yaitu 4,66 \%. Filtrasi menggunakan sedimen poly propilena (SPP) 10 mikron dan dimasukkan kedalam housing filter. Sedangkan perlakuan resin anion dan kation dilakukan dalam tabung Fiber Reinforced Plastic (FRP) dengan ketinggian $60 \mathrm{~cm}$ dimana jenis alirannya menggunakan aliran ke atas dengan waktu tinggal 30 menit.

Hasil perlakuan penelitian dianalisis mengacu pada parameter fisika, kimia anorganik, kimia organik, dan bakteriologi (sebagaimana Tabel 1.)

\section{HASIL DAN PEMBAHASAN}

\section{Hasil Penelitian}

Sampel air baku setelah dilakukan treatment berturut turut : Sucolite SP 211 sebagai Coagulant Aid pada tanki koagulan, kemudian treatment filtrasi menggunakan sedimen poly propilena (SPP) pada housing filter. Selanjutnya berturut turut treatment Ferrolite dan Manganese Greensand pada housing filter, resin anion pada tabung FRP, dan resin kation pada tabung FRP diperoleh data sebagaimana disajikan pada tabel 1 . 
Setyo Purwoto, Rusdiyantoro, \& Budi Prijo S. : Treatment Koagulan, Filtrasi, Ferrolite, Manganese Greensand, dan Resin Pada Air Baku Dalam Penurunan TDS, Kekeruhan, Kesadahan, Khlorida, Mangan, dan E Koli

Tabel 1. Parameter Hasil Uji Laboratorium Sebelum dan Setelah Treatment

\begin{tabular}{|c|c|c|c|c|}
\hline No & Parameter & Satuan & Sampel & Hasil Treatment \\
\hline \multicolumn{5}{|c|}{ A. FISIKA } \\
\hline 1 & Bau & - & Tidak berbau & Tidak berbau \\
\hline 2 & Total Disolved Solid (TDS) & $\mathrm{mg} / \mathrm{L}$ & 6.520 & 5.160 \\
\hline 3 & Kekeruhan & Skala NTU & 6,650 & 0,350 \\
\hline 4 & Rasa & - & Berasa & Berasa \\
\hline 5 & Suhu & $\mathrm{oC}$ & 26,00 & 27,500 \\
\hline 6 & Warna & Unit PtCo & 1,514 & 1,018 \\
\hline 7 & Daya Hantar Listrik (DHL) & $\mathrm{mhos} / \mathrm{cm}$ & tidak diukur & tidak diukur \\
\hline \multicolumn{5}{|c|}{ B. KIMIA } \\
\hline \multicolumn{5}{|c|}{ a. Kimia Anorganik } \\
\hline 1 & Air Raksa & $\mathrm{mg} / \mathrm{L} \mathrm{Hg}$ & $<0,000198$ & $<0,000198$ \\
\hline 2 & Arsen & $\mathrm{mg} / \mathrm{L} \mathrm{As}$ & - & - \\
\hline 3 & Besi & $\mathrm{mg} / \mathrm{L} \mathrm{Fe}$ & $<0,0413$ & $<0,0413$ \\
\hline 4 & Fluorida & $\mathrm{mg} / \mathrm{L} \mathrm{F}$ & 0,671 & 0,652 \\
\hline 5 & Kadmium & $\mathrm{mg} / \mathrm{L} \mathrm{Cd}$ & $<0,00935$ & $<0,00935$ \\
\hline 6 & Kesadahan Total & $\mathrm{mg} / \mathrm{L} \mathrm{CaCO} 3$ & 1.631 & 1.366 \\
\hline 7 & Khlorida & $\mathrm{mg} / \mathrm{L} \mathrm{Cl}$ & $2.782,340$ & $2.489,462$ \\
\hline 8 & Kromium, Val 6 & $\mathrm{mg} / \mathrm{L} \mathrm{Cr}$ & - & - \\
\hline 9 & Mangan & $\mathrm{mg} / \mathrm{L} \mathrm{Mn}$ & 1,512 & 0,277 \\
\hline 10 & Nitrat & $\mathrm{mg} / \mathrm{L}$ NO3-N & 17,485 & 11,130 \\
\hline 11 & Nitrit & $\mathrm{mg} / \mathrm{L} \mathrm{NO} 2-\mathrm{N}$ & 0,918 & 0,312 \\
\hline 12 & $\mathrm{pH}$ & - & 7,290 & 7,810 \\
\hline 13 & Selenium & $\mathrm{mg} / \mathrm{L} \mathrm{Se}$ & - & - \\
\hline 14 & Seng & $\mathrm{mg} / \mathrm{L} \mathrm{Zn}$ & 0,029 & 0,019 \\
\hline 15 & Sianida & $\mathrm{mg} / \mathrm{L} \mathrm{CN}$ & 0,003 & 0,002 \\
\hline 16 & Sulfat & $\mathrm{mg} / \mathrm{L} \mathrm{SO} 4$ & 465,325 & 369,760 \\
\hline & Timbal & $\mathrm{mg} / \mathrm{L} \mathrm{Pb}$ & $<0,0547$ & $<0,0547$ \\
\hline \multicolumn{5}{|c|}{ b. Kimia Organik } \\
\hline 1 & Zat Organik & mg/L KMnO4 & 9,159 & 10,228 \\
\hline 2 & Detergent & $\mathrm{mg} / \mathrm{L} \mathrm{LAS}$ & 0.034 & $<0,00526$ \\
\hline \multicolumn{5}{|c|}{ C. BAKTERIOLOGI } \\
\hline 1 & Total Koliform & MPN/100 ml & 5.200 & 2.060 \\
\hline
\end{tabular}

\section{Pembahasan}

Parameter yang mengalami penurunan secara signifikan adalah ; Total Disolved Solid (TDS), Kekeruhan,
Kesadahan Total, Khlorida, Mangan, dan Total Koliform disajikan pada Tabel 2. 
Setyo Purwoto, Rusdiyantoro, \& Budi Prijo S. : Treatment Koagulan, Filtrasi, Ferrolite, Manganese Greensand, dan Resin Pada Air Baku Dalam Penurunan TDS, Kekeruhan, Kesadahan, Khlorida, Mangan, dan E Koli

Tabel 2. Removal Parameter Antara Sampel Dan Hasil Treatment

\begin{tabular}{llllll}
\hline No & Parameter & Satuan & Sampel & $\begin{array}{l}\text { Hasil } \\
\text { Treatment }\end{array}$ & penurunan \\
\hline 1 & Total Disolved Solid (TDS) & mg/L & 6.520 & 5.160 & 1.360 \\
2 & Kekeruhan & Skala NTU & 6,650 & 0,350 & 6,300 \\
3 & Kesadahan Total & mg/L CaCO3 & $1.631,750$ & $1.366,116$ & 265,634 \\
4 & Khlorida & mg/L Cl & $2.782,340$ & $2.489,462$ & 292,878 \\
5 & Mangan & mg/L Mn & 1,512 & 0,277 & 1,235 \\
6 & Total Koliform & MPN/100 mL & 5.200 & 2.060 & 3.140 \\
\hline
\end{tabular}

Tentang Total Koliform ;

Treatment penelitian ini mampu menurunkan total koliform sangat signifikan, yaitu sebesar 3.140 satuan MPN/100 ml lebih besar jika dibanding dengan temuan Rachmah, N. \& Purwoto, S. (2014) yang menggunakan media manganese green sand sebagai post treatment dimana diperoleh penurunan e koli sebesar 800 satuan dari pada menit ke-15 (dari > 2400 MPN $/ 100 \mathrm{ml}$ turun menjadi 1600 MPN/100 ml).

Contoh sampel air baku menurut (Purwoto, S. 2014) pada Tabel 3., terdapat Total Koliform 1.100 satuan. Sedangkan Total Koliform dalam penelitian ini turun sebesar 3.140 satuan. Dengan demikian jika treatment sebagaimana penelitian ini dilakukan untuk contoh air yang mengandung e koli sebesar 1.100 satuan seperti air contoh tersebut maka e koli dapat dihilangkan seluruhnya.

Tentang Mangan (Mn) ; Penurunan Mangan dalam penelitian ini sebesar $1,235 \mathrm{mg} / \mathrm{L} \mathrm{Mn}$.
Sedangkan jika dibandingkan dengan temuan (Mandasari, I. et al. 2016) dengan menggunakan metode aktivasi kimia $\mathrm{HCl}-\mathrm{NaOH}$ pada adsorben serbuk gergaji kayu kamper menghasilkan kapasitas adsorpsi 1,698 $\mathrm{mgMn} / \mathrm{g}$ sebesar $98,51 \%$.

Untuk removal Total Disolved Solid (TDS) ;

Hasil treatment koagulan, filtrasi dan absorbsi menggunakan sediment poly propylene (SPP), pengikatan kadar $\mathrm{Fe}$ dan Mn menggunakan ferrolite dan atau Manganese Green Sand, dilanjutkan dengan treatment Ion Exchanger menggunakan resin anion dan resin kation sebagaimana penelitian ini mampu menurunkan TDS sebesar 1.360 satuan (dari 6.520 menjadi 5.160). Sedangkan data menurut (Purwoto, S. 2014) pada Tabel 3., TDS air baku sebesar 1240 satuan. Artinya untuk air tanah pada umumnya jika mengandung sekitar angka tersebut mampu diturunkan TDSnya hingga nol.

Tabel 3. Hasil Analisis Uji Laboratorium Antara Air Baku Dan Hasil Treatment

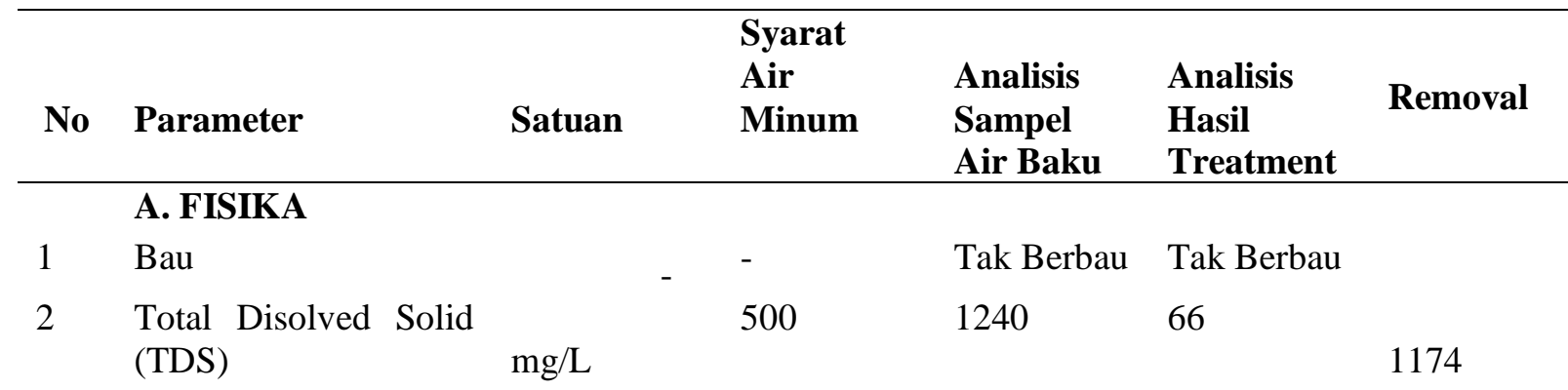


Setyo Purwoto, Rusdiyantoro, \& Budi Prijo S. : Treatment Koagulan, Filtrasi, Ferrolite, Manganese Greensand, dan Resin Pada Air Baku Dalam Penurunan TDS, Kekeruhan, Kesadahan, Khlorida, Mangan, dan E Koli

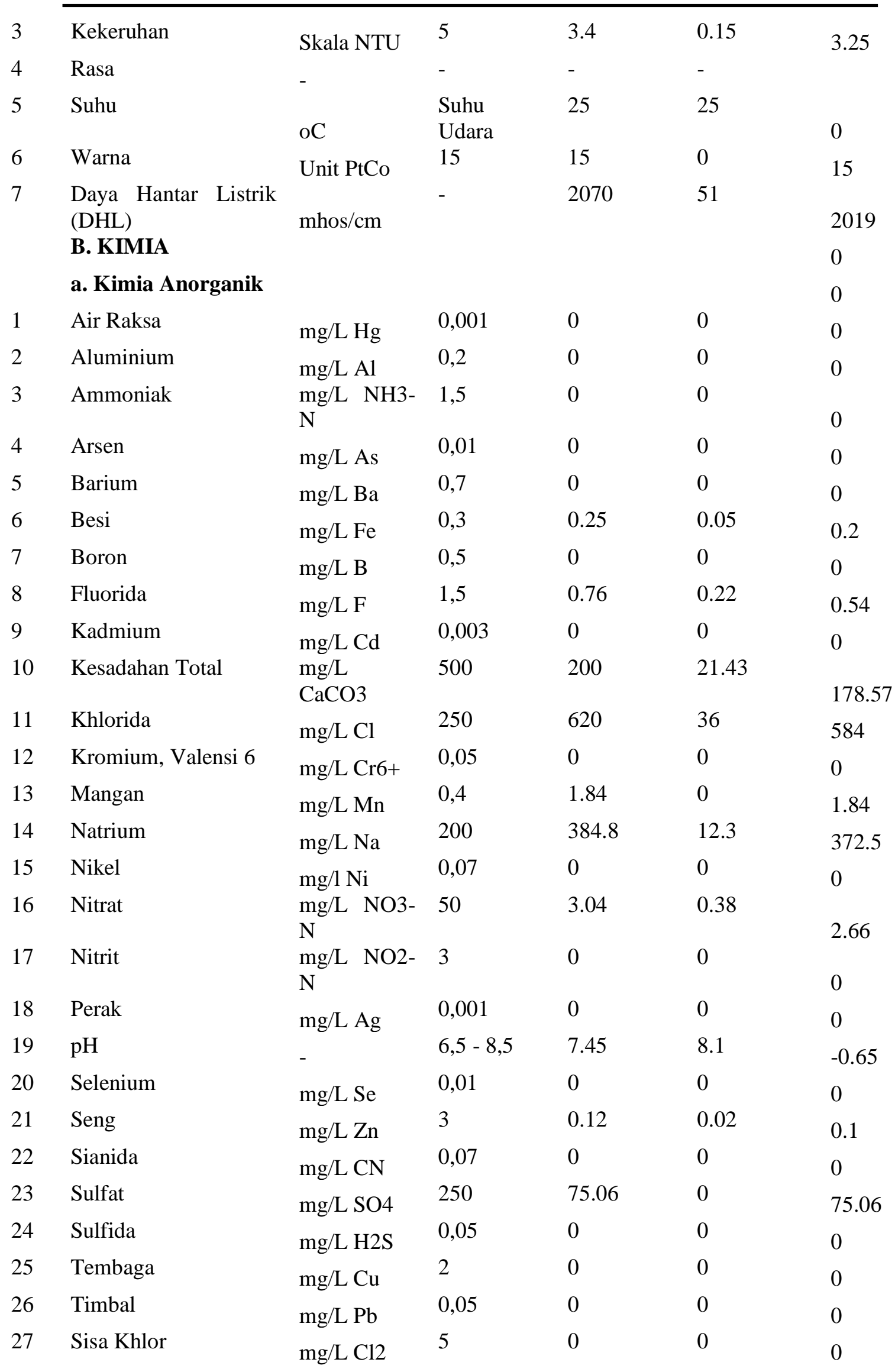


Setyo Purwoto, Rusdiyantoro, \& Budi Prijo S. : Treatment Koagulan, Filtrasi, Ferrolite, Manganese Greensand, dan Resin Pada Air Baku Dalam Penurunan TDS, Kekeruhan, Kesadahan, Khlorida, Mangan, dan E Koli

\begin{tabular}{lllllll}
\hline \multicolumn{1}{c}{ b. Kimia Organik } & & & & \\
1 & Zat Organik & mg/L & 10 & 3.92 & 3.01 & 0 \\
2 & $\begin{array}{l}\text { KMnO4 } \\
\text { Cetergent }\end{array}$ & mg/L LAS & 0,05 & 0.08 & 0 & 0.91 \\
& $\begin{array}{l}\text { C. } \\
\text { BAKTERIOLOGI } \\
\text { Total Koliform }\end{array}$ & $\begin{array}{l}\text { MPN/100 } \\
\mathrm{mL}\end{array}$ & 0 & 1100 & 33 & 0.08 \\
\hline
\end{tabular}

Sumber : Purwoto, S., Sopandi, T., \& Nurcahyanie, Y.D. (2014)

Tentang penurunan klorida

Mengacu pada Tabel 3., Khlorida

pada air baku sebesar 620 satuan.

Sedangkan hasil treatment penelitian ini mampu menurunkan khlorida sebanyak 292,878 satuan, yang berarti mampu menurunkan kandungan hingga memenuhi persyaratan air bersih yaitu sebesar 600 (maksimum). Menurut temuan (Kurniawan, A. et al. 2014) bahwa zeolit alam dimodifikasi dengan penambahan HDTMA-Br dapat menurunkan klorida sebesar 0.85 g/liter.

Tentang kekeruhan ;

Air contoh yang lain dijumpai pada Purwoto, S. (2016) pada Tabel 4. Untuk kekeruhan 31.2 satuan dapat diturunkan sebesar 6,3 satuan (jika menggunakan perlakuan sebegaimana penelitian ini) hingga menjadi 24,9 satuan yang berarti memenuhi persyaratan permenkes nomor 416 tahun 1990 tentang air bersih yang mensyaratkan kekeruhan maksimum sebesar 25 satuan. Dibandingkan dengan temuan (Rusdi et al. 2014) penggunaan biji kelor pada konsentrasi $400 \mathrm{ppm}$ dan waktu pengendapan 12 menit diperoleh penurunan kekeruhan 66,3\%.

Tentang kesadahan ;

Removal Kesadahan Total pada penelitian ini sebesar 265,634 $\mathrm{mg} / \mathrm{L}$ $\mathrm{CaCO} 3$. Mengacu pada Permenkes Republik Indonesia nomor : 416/MENKES/PER/IX/1990 tentang PERSYARATAN KUALITAS AIR BERSIH mensyaratkan kadar maksimum kesadahan sebesar $500 \mathrm{mg} / \mathrm{L}$ $\mathrm{CaCO}$. Air contoh menurut Tabel 4., bahwa air baku mengandung kesadahan sebesar 385.71 satuan. Dapat diartikan bahwa jika treatment sebagaimana penelitian ini dilakukan akan dapat menurunkan kadar kesadahan hingga sekitar 120 satuan. Husaini, et al. (2006) menyimpulkan bahwa selektivitas pertukaran ion zeolit terhadap kesadahan sebagai $\mathrm{Ca}^{+2}$ sebesar 2,3129 ppm.

Tabel 4. Parameter Antara Air Baku Dan Treatment Ferrolite, MGS, Dan Resin

\begin{tabular}{ccccl}
\hline No & Parameter & Satuan & $\begin{array}{c}\text { Syarat Air Syarat Air } \\
\text { Bersih*) }\end{array}$ & Air Baku \\
& & & $\begin{array}{l}\text { Treatment Removal } \\
\text { Ferrolite, } \\
\text { MGS , dan } \\
\text { resin }\end{array}$ \\
\hline
\end{tabular}

A. FISIKA

$1 \quad \mathrm{Bau}$

2 Total

Disolved

Solid (TDS)

3 Kekeruhan tak berbau

$\mathrm{mg} / \mathrm{L} \quad 1500$

Skala NTU
25
Tak berbau Tak Berbau

$558 \quad 538$

20.00

$$
500
$$

5

31.2

0.84

30.36 
Setyo Purwoto, Rusdiyantoro, \& Budi Prijo S. : Treatment Koagulan, Filtrasi, Ferrolite, Manganese Greensand, dan Resin Pada Air Baku Dalam Penurunan TDS, Kekeruhan, Kesadahan, Khlorida, Mangan, dan E Koli

\begin{tabular}{|c|c|c|c|c|c|c|c|}
\hline 4 & Rasa & - & tak & - & - & - & \\
\hline 5 & Suhu & $\mathrm{oC}$ & suhu & Suhu Udara & 25 & 25 & 0.00 \\
\hline 6. & $\begin{array}{l}\text { Warna } \\
\text { Kimia }\end{array}$ & Unit PtCo & $\begin{array}{r}\text { udara } \\
50\end{array}$ & 15 & 130 & 10 & 120.00 \\
\hline B. & a. Kimia Anor & ganik & & & & & \\
\hline 1 & Air Raksa & $\mathrm{mg} / \mathrm{L} \mathrm{Hg}$ & 0.001 & 0,001 & 0 & 0 & 0.00 \\
\hline 2 & Arsen & $\mathrm{mg} / \mathrm{L} \mathrm{As}$ & 0.05 & 0,01 & 0 & 0 & 0.00 \\
\hline 3 & Besi & $\mathrm{mg} / \mathrm{L} \mathrm{Fe}$ & 1 & 0,3 & 2.54 & 0.12 & 2.42 \\
\hline 4 & Fluorida & $\mathrm{mg} / \mathrm{L} \mathrm{F}$ & 1.5 & 1,5 & 0.62 & 0.61 & 0.01 \\
\hline 5 & Kadmium & mg/L Cd & 0.005 & 0,003 & 0 & 0 & 0.00 \\
\hline 6 & Kesadahan & $\mathrm{mg} / \mathrm{L} \mathrm{CaCO} 3$ & 500 & 500 & 385.71 & 164.2 & 221.43 \\
\hline 7 & $\begin{array}{l}\text { Total } \\
\text { Khlorida }\end{array}$ & $\mathrm{mg} / \mathrm{L} \mathrm{Cl}$ & 600 & 250 & 100 & ${ }^{8} 232$ & -13200 \\
\hline 8 & Kromium VI & $\mathrm{mg} / \mathrm{L} \mathrm{Cr}$ & 0.05 & 0,05 & 38.17 & 0 & 38.17 \\
\hline 9 & Mangan & $\mathrm{mg} / \mathrm{L} \mathrm{Mn}$ & 0.5 & 0,4 & 6.18 & 0 & 6.18 \\
\hline 10 & Nitrat & $\begin{array}{c}\mathrm{mg} / \mathrm{L} \\
\mathrm{NO}-\mathrm{N}\end{array}$ & 10 & 50 & 0.13 & 1.07 & -0.94 \\
\hline 11 & Nitrit & $\begin{array}{l}\mathrm{mg} / \mathrm{L} \\
\mathrm{NO} 2-\mathrm{N}\end{array}$ & 1 & 3 & 0.087 & 0.03 & 0.06 \\
\hline 12 & $\mathrm{pH}$ & - & $6,5-9,0$ & $6,5-8,5$ & 6.95 & 8.8 & -1.85 \\
\hline 13 & Selenium & $\mathrm{mg} / \mathrm{L} \mathrm{Se}$ & 0.01 & 0,01 & 0 & 0 & 0.00 \\
\hline 14 & Seng & $\mathrm{mg} / \mathrm{L} \mathrm{Zn}$ & 15 & 3 & 0.09 & 0.07 & 0.02 \\
\hline 15 & Sianida & $\mathrm{mg} / \mathrm{L} \mathrm{CN}$ & 0.1 & 0,07 & 0 & 0 & 0.00 \\
\hline 16 & Sulfat & $\mathrm{mg} / \mathrm{L} \mathrm{SO} 4$ & 400 & 250 & 38.17 & 17 & 21.17 \\
\hline 17 & $\begin{array}{l}\text { Timbal } \\
\quad \text { b. Kimia Or }\end{array}$ & $\underset{\text { ganik }}{\mathrm{mg} / \mathrm{L} \mathrm{Pb}}$ & 0.05 & 0,01 & 0 & 0 & 0.00 \\
\hline 1 & Zat Organik & $\mathrm{mg} / \mathrm{L} \mathrm{KMnO} 4$ & 10 & 10 & 7.58 & 20.86 & -13.28 \\
\hline 2 & Detergent & $\mathrm{mg} / \mathrm{L}$ LAS & 0.5 & 0,05 & 0.05 & 0.03 & 0.02 \\
\hline
\end{tabular}

\section{KESIMPULAN}

Treatment koagulan, filtrasi, ferrolite, manganese greensand, dan resin pada air baku dapat menurunkan ; Total Disolved Solid (TDS) $1.360 \mathrm{mg} /$ L, kekeruhan sebesar 6,3 skala Turbidity NTU, kesadahan total (total hardness) 265,634 mg / L CaCO3, khlorida $292,878 \mathrm{mg} / \mathrm{L} \mathrm{Cl} \mathrm{-,} \mathrm{Mangan} \mathrm{1,235}$ $\mathrm{mg} / \mathrm{L} \mathrm{Mn}$, dan Total Coliform (e koli) $3.140 \mathrm{MPN} / 100 \mathrm{~mL}$

\section{UCAPAN TERIMA KASIH}

Para penulis mengucapkan terima kasih kepada Direktur Penelitian dan Pengabdian Masyarakat, Kementerian Riset, Teknologi, dan Pendidikan Tinggi, Indonesia, yang telah mendanai penelitian ini dalam skema Penelitian Strategis Nasional Institusi (PSNI) tahun anggaran 2018.

\section{DAFTAR PUSTAKA}

Husaini, Soenara T. (2006). "Pengurangan Kesadahan Ca, Mg dan Logam Berat Fe, Mn, Zn dalam Bahan Baku Air Minum dengan Menggunakan Zeolit Asal Cikalong Tasikmalaya" Jurnal Zeolit Indonesia 5(01), ISSN:1411-6723.

Indonesia, Permenkes. (1990), "Persyaratan Kualitas Air Bersih", Nomor ; 416/MENKES/PER/IX/ 1990.

Kurniawan, A. , Bambang Rahadi, B., Susanawati, L.D. (2014). "Studi Pengaruh Zeolit Alam Termodifikasi Hdtma Terhadap Penurunan Salinitas Air Payau".Jurnal 
Setyo Purwoto, Rusdiyantoro, \& Budi Prijo S. : Treatment Koagulan, Filtrasi, Ferrolite, Manganese Greensand, dan Resin Pada Air Baku Dalam Penurunan TDS, Kekeruhan, Kesadahan, Khlorida, Mangan, dan E Koli

Sumber daya
jsal.ub.ac.id/index.php/jsal/article/download/130/108.

Montgomery, J.M., (2005), "Water Treatment Principles and Design". Johan Weley Inc. USA.

Nurhayati, I., \& Purwoto, S. (2014), "The Combination of Coagulant Aid, Ion Exchanger, and Reverse Osmosis (RO ) on Brackish Water Treatment" Journal of Natural Sciences Research 4(24), 26-30.

Purwoto, S. (2009), "Desalinasi Air Payau Secara Ion Exchange dengan Treatmen Resin Sintetis" Waktu 7(01), 52-59.

Purwoto, S., Sopandi, T., Kusuma, P.S.W., \& Nurcahyanie, Y.D. (2014), "Removal Parameters of Clean Water using Treatment; Sediment Poly Propylene, Carbon Block, Manganese Zeolite, Ion Exchange, and Reverse Osmosis (RO)." Journal of Environment and Earth Science 4(23), 72- 77.

Purwoto, S., Sopandi, T., \& Nurcahyanie, Y.D. (2014), " Human Performance Learning Through Technology Brackish Water Treatment In ; Filtration, Ion Exchanger, and Reverse Osmosis." The 5th International Conference on Education of Adi Buana (ICETA-5) ISBN: 978-979-3870-58-8, Mei 2014, 350 - 359.

Purwoto, S., Purwanto, T., \& Hakim, L. (2015), "Penjernihan Air Sungai Dengan Perlakuan Koagulasi, Filtrasi, Absorbsi dan Pertukaran Ion." WAKTU ISSN : $1412-1867, \mathbf{1 3}(2), 45-53$.

Purwoto, S., Sutrisno, J., (2016), "Pengolahan Air Tanah Berbasis Treatment Ferrolite, Manganese Zeolite, dan IonExchange" Jurnal Teknik WAKTU- ISSN : 1412-1867; 14(2), 21-31.

Purwoto, S., Sutrisno, J., (2017), "Learning About Water Purification Using Filtration And Reverse Osmosis" The 9th International Conference on Education of Adi Buana (ICETA-9) ISBN ; 9789798559976, August 2017, 205-211.

Rachmah, N. \& Purwoto, S. (2014), "Efektifitas Penurunan Mn dan Total Coliform Pada Air Sumur Gali Berbasis Zeolit" Jurnal WAKTU 12(01), 1-7.

Rusdi, Purnomo, S.T.B, Pratama, R. (2014). "Pengaruh Konsentrasi Dan Waktu Pengendapan Biji Kelor Terhadap pH, Kekeruhan Dan Warna Air Waduk Krenceng" Jurnal Integrasi Proses 5(01), ; 46 - 50.

Taffarel , S. R., Rubio, J., (2010), "Removal of $\mathrm{Mn}^{2+}$ from aqueous solution by manganese oxide coated zeolite." Minerals Engineering 23(14): 1131-1138. 